\title{
PREVALENSI KECACINGAN PADA MURID SEKOLAH DASAR NEGERI DI DESA CIHANJUANG RAHAYU PARONGPONG BANDUNG BARAT
}

\author{
Mettison M. Silitonga, ${ }^{1}$ Untung Sudharmono, ${ }^{2}$ Masta Hutasoit \\ ${ }^{1} J u r u s a n$ Biologi Fakultas Matematika \& IImu Pengetahuan Alam Unai \\ ${ }^{2}$ Fakultas Keperawatan Unai
}

\begin{abstract}
ABSTRAK
Penyakit infeksi akibat cacing usus di Indonesia masih cukup tinggi. Hal ini berhubungan dengan kurang diperhatikannya pola perilaku hidup bersih dan sehat. Penyakit cacing dapat mengganggu pertumbuhan anak dan menghambat prestasi belajar murid sekolah dasar. Tujuan penelitian ini adalah untuk memperoleh data prevalensi kecacingan pada murid Sekolah Dasar Negeri di Desa Cihanjuang Rahayu. Penelitian ini menggunakan metode epidemiologik observasional dengan bentuk dan rancangan prevalensi selektif. Objek penelitian ini adalah sampel tinja murid-murid SD Kelas III hingga Kelas V dari empat SD yang berbeda selama 25-27 juni 2008. Pemilihan sampel dilakukan dengan purposive sampling design. Sampel tinja diperiksa menggunakan teknik sediaan tebal atau teknik Kato. Dari 142 sampel yang diperiksa, ditemukan 22 sampel yang positif mengandung telur atau larva cacing, yaitu: 12 sampel mengandung cacing $A$. lumbricoides, 7 sampel mengandung cacing $T$. trichiura, 1 sampel mengandung $E$. vermicularis, dan 2 sampel mengandung cacing tambang. Prevalensi kecacingan pada murid SDN di Desa Cihanjuang Rahayu adalah 15,5\%. Angka ini menunjukkan bahwa ada sebanyak 15,5\% murid-murid SDN terinfeksi atau mengidap penyakit cacing.
\end{abstract}

Kata kunci: Prevalensi, cacing usus, SDN, Cihanjuang Rahayu

\section{PREVALENCE OF HELMINTHIC DISEASE AMONG GOVERNMENT ELEMENTARY SCHOOL STUDENTS AT CIHANJUANG RAHAYU VILLAGE PARONGPONG, WEST BANDUNG}

\begin{abstract}
The prevalence of helminthic disease in Indonesia is still high. This is due to the negligence of healthy life style. Helminthic disease may disrupt physical growth and development of a child and even lowers his intellectual ability. The purpose of this research was to measure the prevalence rate of helminthic disease among Government Elementary School Students in Cihanjuang Rahayu Village. The research was conducted by using observational epidemiologic method. The object of the research was the stool of third to fifth grade pupils from four different elementary schools during 25-27 june 2008. The sample was chose by using purposive sampling design and the stool was observed with Kato technique. From 142 samples, it was found out that 22 samples were positive with egg and larva of helminth, which further classification as follows: A. limbriocoides, T. trichiura, E. Vermicularis, and N. americanus/A. duododenale were found in 12, 7, 1, and 2 samples, respectively. The prevalence of helminthic disease among government elementary students in Cihanjuang Rahayu village was 15.5 percent. This number shows that there are 15,5 percent students infected by helminthic disease.
\end{abstract}

Key words: Prevalence, helminthes, elementary school, Cihanjuang Rahayu

\author{
Alamat Korespondensi \\ Mettison M. Silitonga \\ Jurusan Biologi Fakultas Matematika \& IImu Pengetahuan Alam UNAI \\ Telp: 081802033777 \\ Email: mettison@gmail.com; msilitonga@unai.edu
}




\section{PENDAHULUAN}

Penyakit akibat cacing masih merupakan penyakit endemik yang dapat ditemukan di berbagai tempat di Indonesia. Prevalensi infeksi cacing yang ditularkan melalui tanah (soiltransmitted helminth) masih cukup tinggi dan infeksi cacing ini dapat menyebabkan masalah kesehatan masyarakat, khususnya pada anak yang masih dalam usia sekolah dasar.

Cacing yang ditularkan melalui tanah mempunyai bentuk infektif di tanah yang sesuai. Ada beberapa jenis cacing yang ditularkan melalui tanah yang penting pada manusia, yaitu: Ascaris lumbricoides, Trichuris trichiura, Necator americanus, Ankylostoma duodenale, dan Strongyloides stercoralis. ${ }^{1,2}$

Prevalensi kecacingan ini bervariasi dari satu daerah ke daerah lain, terpengaruhi beberapa faktor, di antaranya adalah daerah tempat tinggal (desa atau kota, kumuh, dll), kelompok usia yang diperiksa, teknik pemeriksaan, kebiasaan penduduk setempat (tempat buang air besar, cuci tangan sebelum makan, tidak beralas kaki, dII), dan pekerjaan penduduk. Prevalensinya di Indonesia masih cukup tinggi dan cacing usus yang tertinggi prevalensinya adalah $A$. lumbricoides. ${ }^{2}$

Golongan anak sekolah dasar merupakan kelompok usia yang rentan terhadap infeksi cacing. Hal ini disebabkan oleh kebiasaan bermain pada anak yang tidak memperhatikan kebersihan diri dan lingkungannya. Demikian pula dengan kebiasaan mengkonsumsi makanan yang dijual di sekolah, tanpa memperhatikan higiene serta sanitasi makanan dan lingkungan.

Prevalensi kecacingan di Jawa Barat, khususnya di daerah pedesaan masih cukup tinggi. Berdasarkan hasil penelitian yang dilakukan pada murid Kelas I SDN Kartika XI-12 Desa Karyawangi Kecamatan Parongpong menunjukkan bahwa prevalensi infeksi cacing tambang adalah $24,6 \%$, pada anak laki-laki prevalensinya $22,8 \%$ dan pada anak perempuan adalah $26,9 \%{ }^{3}$

Demikian pula dengan hasil penelitian yang dilakukan pada murid Kelas I SDN Karyawangi Parongpong menunjukkan bahwa dari 72 murid yang diperiksa tinjanya ada sebanyak $72,2 \%$ yang positif terinfeksi cacing Ascaris lumbricoides. ${ }^{4}$

Beberapa penelitian sebelumnya menunjukkan bahwa prevalensi kecacingan pada murid sekolah dasar masih tergolong tinggi. Penelitian ini bertujuan untuk memperoleh data prevalensi kecacingan pada murid SDN di Desa Cihanjuang Rahayu. Penelitian ini penting sebagai langkah awal untuk pemberantasan penyakit infeksi akibat kecacingan pada murid sekolah dasar, sehingga diharapkan pada waktu yang akan datang dapat dilakukan survei menyeluruh terhadap siswa/siswi SDN lainnya.
Jika prevalensi kecacingan yang diperoleh lebih dari $20 \%$, maka perlu dilakukan pengobatan masal. ${ }^{5}$ Diharapkan dengan pemberantasan kecacingan ini akan dapat meningkatkan prestasi belajar siswa-siswi di sekolah.

\section{METODE}

Penelitian ini merupakan penelitian epidemiologik observasional menggunakan bentuk dan rancangan prevalensi selektif atau selective prevalence design. Populasi sasaran adalah murid-murid Sekolah Dasar Negeri yang berada di Desa Cihanjuang Rahayu. Objek penelitian ini adalah sampel tinja yang dikumpulkan dari murid-murid SD tersebut.

Populasi subjek dalam penelitian ini adalah murid-murid SDN di Cihanjuang Rahayu yang berada pada empat Sekolah Dasar, yaitu: SDN Cihanjuang II, SDN Mekar Rahayu, SDN Cihanjuang IV, dan SDN Tutugan Rahayu.

Teknik pengambilan sampel menggunakan purposive sampling design, murid-murid SD yang diperiksa terbatas hanya pada Kelas III, Kelas IV, dan Kelas V. Penelitian ini dilaksanakan pada tanggal 25-27 Juni 2008 dengan sampel tinja yang berhasil dikumpulkan sebanyak 142 tabung.

Selanjutnya, dilakukan pemeriksaan sampel tinja yang telah dikumpulkan menggunakan teknik sediaan tebal (cellophane-covered thick smear technic) atau disebut teknik Kato. Pada teknik ini digunakan selofan (cellophane tape) sebagai pengganti kaca tutup. Telur cacing dapat ditemukan lebih banyak, sebab tinja yang diperiksa lebih banyak. Teknik ini dianjurkan pula untuk pemeriksaan tinja yang melibatkan jumlah sampel yang besar seperti pada penelitian epidemiologi, karena lebih sederhana dan murah, serta morfologi telur cacing juga cukup jelas. ${ }^{6,7}$

Prevalensi kecacingan adalah jumlah sampel tinja yang positif terinfeksi cacing dibagi dengan jumlah murid yang diperiksa dikalikan dengan $100 \%{ }^{5}$

\section{HASIL}

Dari sebanyak 142 sampel tinja yang berhasil dikumpulkan, diperoleh hasil pemeriksaan tinja seperti tertera pada Tabel 1.

Tabel 1 menunjukkan bahwa dari 16 sampel tinja yang dikumpulkan dari SD Cihanjuang II, maka ditemukan ada dua sampel tinja yang positif terinfeksi cacing, yaitu cacing $A$. lumbricoides dan T. trichiura. Sedangkan dari 44 sampel tinja yang berasal dari murid SDN Tutugan Rahayu, ada tujuh sampel tinja yang positif terinfeksi cacing dan jenis cacing yang ditemukan adalah $A$. lumbricoides dan $T$. 


\begin{tabular}{lcccccc}
\hline \multicolumn{1}{c}{ SDN } & $\begin{array}{c}\text { Jumlah } \\
\text { Sample }\end{array}$ & $\begin{array}{c}\text { Sampel } \\
\text { Positif } \\
(\%)\end{array}$ & A. Iumbricoides & T. trichiura & E. vernikularis & $\begin{array}{c}\text { N. americanus \& } \\
\text { A. duodenale }\end{array}$ \\
\hline Cihanjuang II & 16 & 12,5 & 1 & 1 & - & - \\
$\quad \begin{array}{l}\text { Tutugan } \\
\text { Rahayu }\end{array}$ & 44 & 15,9 & 4 & 3 & - & - \\
$\quad \begin{array}{l}\text { Cihanjuang IV } \\
\text { Mekar }\end{array}$ & 39 & 15,4 & 2 & 2 & 1 & 1 \\
$\begin{array}{l}\text { Rahayu } \\
\text { Total }\end{array}$ & 43 & 16,3 & 5 & 1 & - & 1 \\
\hline
\end{tabular}

Demikian pula hasil yang diperoleh dari pemeriksaan tinja pada murid SDN Cihanjuang IV, dari 39 sampel tinja yang dikumpulkan maka ditemukan ada enam sampel yang positif terinfeksi cacing dari jenis $A$. lumbricoides, $T$. trichiura, E. vermicularis, dan cacing tambang. Sedangkan dari hasil pemeriksaan 43 sampel tinja murid SDN Mekar Rahayu, terdapat tujuh sampel tinja yang positif terinfeksi cacing, jenis cacing yang ditemukan adalah cacing $A$. lumbricoides, T. trichiura, dan cacing tambang.

Jadi, dari seluruh sampel tinja yang berjumlah 142 sampel yang diperiksa, maka

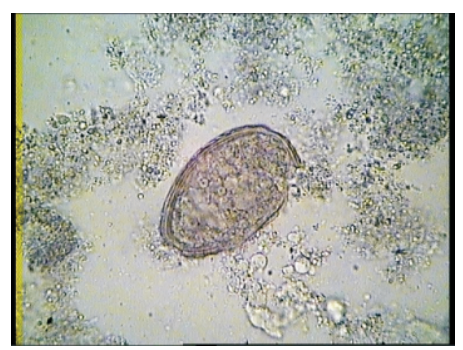

Gambar 1 Telur A. lumbricoides yang Berasal Sampel Tinja

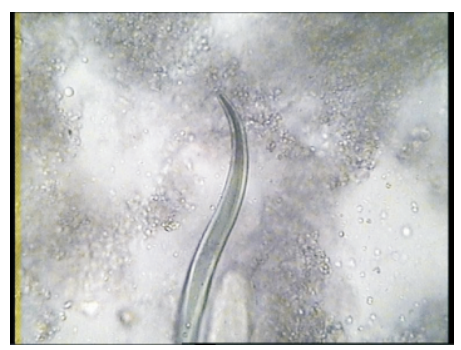

Gambar 3 Larva A. lumbricoides yang Berasal dari Sampel Tinja

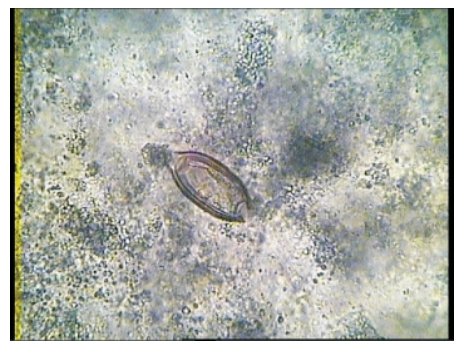

Gambar 5 Telur T. trichiura yang Berasal dari Sampel Tinja ditemukan sebanyak 22 sampel tinja yang positif. Hal ini menunjukkan bahwa ratarata prevalensi kecacingan di SDN di Desa Cihanjuang Rahayu sebesar $15,5 \%$.

Gambar berikut ini adalah gambar yang diambil dari hasil pemeriksaaan tinja murid SDN di Desa Cihanjuang Rahayu.

\section{PEMBAHASAN}

Dari hasil pemeriksaan sampel tinja yang berasal dari murid SDN Cihanjuang II, maka ditemu-

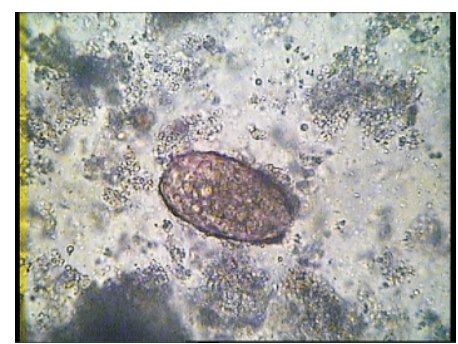

\section{Gambar 2 Telur A. lumbricoides Fertil} Berasal dari Sampel Tinja

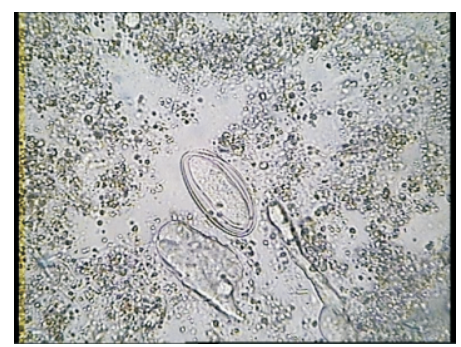

Gambar 4 Telur E.Vermicularis yang

Berasal dari Sampel Tinja

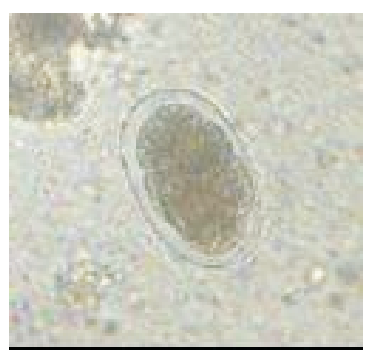

Gambar 6 Telur Cacing Tambang yang Berasal dari Sampel Tinja 
kan sekitar $12,5 \%$ terinfeksi cacing, dan sampel tinja yang berasal dari murid SDN Tutugan Rahayu, terdapat $15,9 \%$ terinfeksi.

Demikian pula hasil yang diperoleh dari pemeriksaan tinja pada murid SDN Cihanjuang IV, ditemukan sekitar $15,4 \%$ terinfeksi cacing, serta hasil pemeriksaan sampel tinja murid SDN Mekar Rahayu, terdapat 16,3\% yang terinfeksi.

Jenis cacing yang ditemukan pada murid Sekolah Dasar Negeri di Desa Cihanjuang Rahayu adalah cacing $A$. lumbricoides (cacing gelang), T. trichiura (cacing cambuk), E. vermicularis (cacing keremi), serta $N$. americanus dan $A$. duodenale (cacing tambang). ${ }^{8}$

Jenis cacing yang paling banyak ditemukan dalam sampel tinja yang diperiksa dalam penelitian ini adalah cacing gelang $(54,5 \%)$, kemudian diikuti oleh cacing cambuk $(31,8 \%)$ dan cacing tambang $(9,1 \%)$, serta yang paling sedikit adalah cacing keremi $(4,5 \%)$.

Berdasarkan hasil pemeriksaan terhadap 142 sampel tinja yang dikumpulkan dari murid-murid SDN yang berada di Desa Cihanjuang Rahayu, maka ditemukan tingkat prevalensinya sebesar $15,5 \%$.

Prevalensi merupakan suatu ukuran keadaan suatu penyakit di suatu populasi pada suatu waktu atau periode tertentu. ${ }^{9}$ Dengan kata lain, pada saat penelitian ini dilakukan ada sebanyak $15,5 \%$ dari murid-murid SDN terinfeksi atau mengidap penyakit cacing.

Jika prevalensi kecacingan ini lebih dari $20 \%$, maka perlu dilakukan pengobatan masal. ${ }^{5}$ Dalam hal ini, hasil pemeriksaan yang didapat masih lebih rendah dari $20 \%$ sehingga tidak perlu dilakukan pengobatan masal tapi perlu pengobatan individual.

Prevalensi infeksi cacing pada murid sekolah dasar di Desa Cihanjuang ini sebenarnya masih jauh lebih rendah jika dibandingkan dengan hasil penelitian yang dilakukan sebelumnya pada murid Kelas I SDN Kartika XI12 Desa Karyawangi Kecamatan Parongpong yang prevalensinya mencapai $24,6 \%{ }^{3}$

Demikian pula dengan hasil penelitian yang dilakukan pada murid Kelas I SDN Karyawangi Parongpong menunjukkan angka prevalensi kecacingan sebesar $72,2 \%{ }^{4}$ Hasil penelitian ini masih jauh lebih tinggi jika dibandingkan hasil penelitian yang diperoleh dari SDN Cihanjuang Rahayu.

Prevalensi kecacingan yang cukup tinggi juga diperoleh dari studi yang dilakukan pada murid sekolah dasar di Pemalang Jawa Tengah, didapatkan infestasi cacing gelang $(38,8-47,1 \%)$ dan cacing tambang $(18,8-$ $39,6 \%$ ) yang merupakan penyakit cacing yang paling sering dijumpai. ${ }^{10}$

Penyakit infeksi dan parasit lainnya pada kelompok usia 5-44 tahun di Provinsi Jawa Barat pada tahun 2006 ada sebesar 0,91\% penderita yang rawat jalan dan $2,12 \%$ penderita yang rawat inap. Hal ini menunjukkan bahwa pada usia sekolah dan usia produktif masih sangat sedikit yang datang berobat ke rumah sakit, dan tampaknya lebih banyak kasus yang terjadi di masyarakat jika dibandingkan dengan data yang tercatat. ${ }^{11}$

Sebenarnya ada berbagai macam faktor yang mempengaruhi prevalensi kecacingan di suatu daerah. Hal ini berhubungan dengan pola perilaku hidup bersih dan sehat yang memperhatikan higienis dan sanitasi lingkungan.

Perilaku hidup bersih dan sehat merupakan sekumpulan tindakan (perilaku) yang dipraktikkan atas dasar kesadaran sebagai hasil pembelajaran, yang menjadikan seseorang atau keluarga dapat menolong diri sendiri (memecahkan masalah-masalah) di bidang kesehatan, serta berperan aktif dalam mewujudkan kesehatan masyarakatnya. Pelaksanaan perilaku hidup bersih dan sehat secara langsung maupun tidak langsung berpengaruh terhadap penanggulangan masalah kesehatan melalui pencegahan terjadinya kesakitan maupun kematian. Pembinaan hidup bersih dan sehat ini dilaksanakan baik di rumah tangga, di sekolah, di tempat kerja, serta di tempat umum dan sarana kesehatan. Indikator perilaku hidup bersih dan sehat antara lain, makan dengan gizi berimbang, ketersediaan air bersih, adanya jamban, tingkat kepadatan hunian, dan lain-lain. ${ }^{11}$

Sistem pembuangan kotoran manusia melalui jamban sangat erat kaitannya dengan kondisi fisik lingkungan dan risiko penularan penyakit khususnya penyakit infeksi saluran pencernaan. Pada tahun 2006, ada sebesar $60,77 \%$ rumah tangga mempunyai fasilitas tempat pembuangan kotoran manusia milik sendiri, $13,53 \%$ menggunakan fasilitas milik bersama, $10,93 \%$ menggunakan fasilitas milik umum, dan $14,77 \%$ tidak mempunyai fasilitas tempat pembuangan kotoran. Persentase rumah tangga yang mempunyai tempat penampungan pembuangan tinja hanya $47,46 \%$ dan yang lainnya melalui kolam/sawah $15,27 \%$, sungai/ danau/laut 22,21\%, lobang tanah $11,99 \%$, dan pantai/kebun/ lainnya $1,44 \%{ }^{11}$

Kunci pemberantasan kecacingan adalah memperbaiki higiene dan sanitasi lingkungan. Misalnya, tidak menyiram kebun sayur dengan air got yang tercemar tinja. Sebaiknya, bilas sayur mentah dengan air mengalir atau mencelupkannya beberapa detik kedalam air mendidih. Juga tidak jajan di sembarang tempat, apalagi jajanan yang terbuka. Biasakan pula mencuci tangan sebelum makan, bukan hanya sesudah makan. Dengan demikian, rantai penularan kecacingan bisa diputus. ${ }^{8}$

\section{Ucapan Terima kasih}

Terima kasih penulis sampaikan kepada Dinas 
Pendidikan Kecamatan Parongpong dan Kepala Sekolah SDN di Desa Cihanjuang Rahayu yang telah membantu dalam pengumpulan tinja. Terima kasih pula disampaikan kepada Lembaga Penelitian Universitas Advent Indonesia yang telah membiayai penelitian ini.

Dari hasil penelitian ini, maka dapatlah disimpulkan bahwa: prevalensi kecacingan pada murid SDN yang terletak di Desa Cihanjuang Rahayu adalah $15,5 \%$. Dari 22 sampel positif, maka ditemukan 12 sampel $(54,5 \%)$ mengandung cacing $A$. lumbricoides, 7 sampel (31,8\%) mengandung cacing $T$. trichiura, 1 sampel $(4,5 \%)$ mengandung $E$. vermicularis, dan 2 sampel $(9,1 \%)$ mengandung cacing tambang. Pencegahan infeksi cacing dapat dilakukan melalui menjaga kebersihan diri dan lingkungan.

\section{DAFTAR PUSTAKA}

1. Onggowaluyo S, Ismid IS. Gangguan fungsi kognitif akibat infeksi cacing yang ditularkan melalui tanah. MKI. 1998;48(5):198-204.

2. Tjitra E. Penelitian-penelitian "soil-transmitted helminth" di Indonesia. Cermin Dunia Kedokteran. 1991;72:12-5.

3. Pasaribu MR. Pemeriksaan infeksi cacing tambang dengan teknik natif pada murid kelas I SDN Kartika XI-12 Desa Karyawangi Parongpong Bandung (Skripsi). Bandung: Universitas Advent Indonesia; 2003. (Skripsi)
4. Frans DA. Prevalensi ascariasis pada murid kelas I SDN Karyawangi Parongpong Bandung (Skripsi). Bandung: Universitas Advent Indonesia; 2003.

5. Prasetyo RH. Helmintologi kedokteran. Yogyakarta: Airlangga University Press; 1996.

6. Ismid IS, Winita R, Sutanto I, Zulhasril, Sjarifuddin PK. Penuntun praktikum parasitologi kedokteran. Jakarta: FKUI; 2000.

7. Iwan A. Survei kecacingan di 3 SDN dan $1 \mathrm{MI}$ Kota Banjar [Online] (diunduh 21 Juli 2008). Tersedia dari: http://www. banjarjabar.go.id/redesign.cetak. php?id=533

8. Departemen Kesehatan RI. Mengintip ulah cacing perut, oh seram... [Online] (diunduh 21 Juli 2008).Tersedia dari: http://www.depkes. go.id/index. php?option =article\&task.

9. Departemen Kesehatan RI. Metodologi penelitian kesehatan - penuntun latihan metode penelitian. Jakarta: Pusat Penelitian Penyakit Tidak Menular; 1999.

10. Rahmat ES, Setianingrum SW. Perbandingan efektivitas pengobatan cacing dengan piperasin vs levamisol pada murid SD. MKI. 1997;47(9):435-40.

11. Departemen Kesehatan Provinsi Jawa Barat. Profil Kesehatan Provinsi Jawa Barat 2006. Bandung: Dinas Kesehatan Propinsi Jawa Barat; 2007. 